UNRAM Law Review is licensed under a Creative Commons Attribution 4.0 International License, which permits unrestricted use, distribution, and reproduction in any medium, ULReV provided the original work is properly cited. p-ISSN: 2548-9267 | e-ISSN : 2549-2365, Open Access at : http://unramlawreview.unram.ac.id/index.php/ulr Volume 5 Nomor 1 April 2021

\title{
A Violation of Woman's Rights Under Tradition of Belis in East Nusa Tenggara, Indonesia
}

\author{
Wawan Suriadi \\ Student LL.M at The National University of Malaysia \\ email : suriadiwawan6@gmail.com \\ Shahrul Mizan bin Ismail \\ Lecturer, Associate Professor, Faculty of Law, The National University of Malaysia \\ email : shahrulmizan@ukm.edu.my
}

\begin{abstract}
Indonesia as a legal state has ratified several instruments of international law in order to protect women's rights. But restraint and violations of women's rights are still common. In East Nusa Tenggara, high dowry or Belis often trigger violence against women. This is triggered by the perception that the transfer of women's rights when the dowry or Belis has been paid by the men to the women's family who ultimately give the ability and arbitrariness of men to commit acts of violence. So, the purpose of this study is to review more comprehensively how the practice of giving Belis or dowry in terms of international law and analyze the extent to which international and national law provides protection for the rights of women who are victims of violence. This research is legal doctrinal research using qualitative method. This research was conducted in literature by studying legislation at the national and international level, books, articles, journals, scientific reports related to the issues studied. From this study, it was found that the practice of giving Belis in the form of dowry in marriage is a cultural practice that is also protected by domestic and international law as part of the way of life or cultural rights. Acts of violence in the form of restraint on women's rights due to the repayment of Belis is a violation of women's human rights. So that these two things must be seen from two different sides. The number of national and international legal instruments does not guarantee that it can overcome the problem of violence against women. The legal culture of society in the form of high legal awareness and the willingness and commitment of the state is one step forward in order to provide protection of women's rights.
\end{abstract}

Keywords : Belis; Woman; Human Rights; Violation; International

\section{INTRODUCTION}

The position of women who are inferior to men is a human rights issue faced by Indonesia. In Belis traditional tradition in East Nusa Tenggara, Indonesia, after the handover of dowry and dowry in the form of livestock, gold, etc., the position of women's rights is fully controlled by men. This triggers human rights violations against women in the form of restraint, torture, etc. Another thing that triggers violence in women is the high amount of Belis desired by women's families. The high amount of dowry or Belis proposed by the women's family triggered the perception for men that "I have bought and paid Belis, so I have the right to do anything about 
what I buy, including women's rights". This is in line with the statement made by one of the women in East Nusa Tenggara, Oma Meri where she said that; ${ }^{1}$

"High dowry encourages the exploitation of women. Because they feel that their wives have been bought with very expensive Belis, they feel they can do anything, then there is sexual violence".

In Alor Nusa Tenggara Timur Indonesia, the value of boys for Alor society is higher than for girls, because men are the successors of their family descendants, although girls will be able to get a high 'Belis' value, in accordance with the position of the family or certain considerations (education, women, employment and others). However, after the woman is given Belis, then the hit 'moko' means that the woman will 'marry in' and belong to the husband's family and lose all rights of the woman. In the traditional Belis tradition, as a wife is required to serve the parents completely, should not return to her birth parents. When there is a problem, the woman should not go home to her birth parents. It then becomes a burden; life is not free and makes women feel like being likened to objects. Alor women in the Belis vortex exist in situations confined by culture and customs. Women become victims of the cost of dowry, namely Belis which are nominally very expensive and rare. As a result, women's rights to educational opportunities, marriage and family building cannot be exercised. ${ }^{234}$

Many cases then occur in the community as a result of the enactment of Belis. First, members of the public who avoid redemption do eloping Belis and get out of their village. They do this because of the high Belis set by the custom. As a second result, the lives of women who marry outside the customary territory become very vulnerable. They are often victims of violence because in general husbands consider having escaped customary obligations and feel free and entitled to violence against their wives without being subjected to customary sanctions. The Women's Division of Flores NTT Indonesia's Volunteer Team for Humanity in its research conducted in 2003-2006 stated that Belis became one of the sources of violence against domestic women, there were about 104 violence caused by Belis or high dowry. ${ }^{56}$

In order to protect human rights, especially women, Indonesia has ratified several instruments of international law. Some of them are (a) International Convention Civil and Political Rights (ICCPR), International Covenant on Economic, Social and Cultural Rights (ICESR), Convention on The Elimination of Racial Discrimination (CERD), Convention on

\footnotetext{
${ }^{1} \mathrm{https}$ //health.detik.com/berita-detikhealth/d-3078669/kekerasan-seksual-di-balik-mahar-perkawinan-di-alor-NTT ,(accessed 21 January 2021)

${ }^{2}$ Sipin Putra. (2020). Women's Opportunity to Get Reproductive Health Services and Rights in Alor Countryside, East Nusa Tenggara, No. 1, VOL.2, Jurnal Inada, p.57

${ }^{3}$ Ibid, p.49

${ }^{4}$ Anil Dawan. (2019). Alor Woman in Belis Cultural Vortex; An Ethnographic Approach Through Cultural Revitalization, No.1, VOL.2, Jurnal Inada, p

${ }^{5}$ Tien Handayani Nafi. (2016). Lidwina Inge Nurtjahyo, Iva Kusuma, Tirtawening Parikesit, The Role of Customary Law in Resolving Cases of Violence Against Women in Kupang, Atambua, and Waingpu, No.2, VOL 46, p.234

${ }^{6}$ Lisa H, Development Challenge in NTT, No. 20, The Smeru Research Institute
} 
The Elimination of Discrimination Against Woman (CEDAW), Declaration on the Elimination of Violence Against Woman (DEVAW), Convention Against Torture and other Cruel, Inhuman or Degrading Treatment or Punishment. The instruments of international law have been regulated in Indonesian laws and regulations. In addition, in order to provide protection for women's rights, Indonesia has established an Institution called the National Commission Against Violence Against Women (KOMNAS Perempuan). The commission was formed to respond to women's rights issues as a human rights issue, especially in terms of violence against women. ${ }^{7}$

The presence of several instruments of international law as well as the establishment of institutions that are national in nature have not been able to remove traditional cultural practices that trigger violations of rights against women, such as discrimination and sexual violence against women. Reported through the Kupang Post news portal (2018) the organization TRuK-F (Volunteer Team for Humanitarian Flores) which is a nongovernmental organization engaged in the field of humanity under the auspices of the monastery sister SSpS, recorded at least 141 cases of violence due to Belis in 2017 in Sikka Regency, Flores (Moa, 2018). In 2020 the National Commission against Violence against Women (KOMNAS Perempuan) released an annual record that states; ${ }^{8}$ throughout 2019 there were 431,471 cases of violence against women consisting of 421,752 cases handled by the Religious Court, 14,719 cases handled by service partner institutions in Indonesia, and 1,419 cases from the KOMNAS Perempuan Service and Referral Unit (UPR). ${ }^{9}$ It is a question of whether this practice is a cultural practice that is left hereditary even though it is then contrary to international human rights principles.

Therefore, this research will try to dissect further with regard to the cultural practices of NTT people who use Belis tradition in marriage that violates the instruments of international law related to human rights. In addition, this study focuses on the extent to which international law and national law provide protection to women who are victims of human rights violations.

\section{METHOD}

This research is doctrinal legal research using qualitative approach. Legal materials are obtained from the study of literature by studying legislation, scientific articles, books, journals, research reports containing legal theories, conceptual foundations, legal doctrines, legal norms related to the problems studied.

\footnotetext{
${ }^{7}$ Romy Patra, Institutional Effectiveness of Komnas Perempuan in Protecting Human Rights for Women in Indonesia

${ }^{8}$ Theresia Christiana Nuwa. (2019). Meaning Belis as Dowry (Case Study on Married Couples Using Belis and Without Belis In Nageko Flores Community, East Nusa Tenggara), Thesis, Department of Communication Sciences, FISIP, Airlangga University, 2019, p8

http://www.jurnalperempuan.org/warta-feminis/kekerasan-terhadap-perempuan-meningkat-delapan-kali-lipat-selama-12-tahun-terakhir, (accessed 21 January 2021)
} 


\section{DISCUSSION}

\section{The practice of giving Belis in The Traditional Marriage of NTT Indonesia People}

First, in order to explain the conceptual foundation, it is necessary to then de-abstract the understanding of Belis itself. Belis is another term of dowry given by the groom to the bride's family. The gift is in the form of property or objects that can be assessed with money. Belis is also interpreted as a ritual of appreciation from the bridegroom's family to the bride's family in building a family relationship is as a sign of gratitude to the family of the woman moved place or clan into the family clan of the bridegroom. Belis is a major part of traditional marriage rituals and determines the validity or not of customary marriages held in exchange for services for the use of paying parents. In this section, in addition to further reviewing how the practice of giving Belis to the traditional marriage of the People of East Nusa Tenggara, this section will also try to answer whether the giving of Belis with high value is a practice to appreciate the dignity of women. ${ }^{10}$

The gift of Belis is seen as a male obligation on the family of women. In NTT indigenous tradition, Belis is a tool to move women who were originally in the father tribe and will be part of her husband's tribe. ${ }^{11}$ Women not only change tribes but will also leave their parents as well as relatives and will stay with the husband's family. The move is the reason why the bridegroom must pay Belis for the family of the bride so that Belis has a meaning that is in return for the services or efforts of parents and also as a form of respect for the bridegroom to the bride and parents of the bride who painstakingly raise their daughters. ${ }^{12}$

In NTT society, the giving of Belis becomes very varied, from the meaning, quantity, and shape of objects to be used as Belis. Belis in Flores East Nusa Tenggara can be gold, money, silver, and animals such as horses, buffaloes, and cows and there are other areas that use Belis with certain items. It depends on the local tribe. However, in general the value of Belis depends on several factors. For marriage, the amount of Belis is influenced by, First, the social status of the family; the higher the social status, the higher the Belis value. Second, it is influenced by the agreement or outcome of negotiations between the male family and the female family. So, the impact of Belis payment must be seen from two sides, firstly the expensive amount of Belis requested by the female family. Second, the perceptions of men after Belis payments that claim that when Belis has been paid in full, then women's rights are automatically male ownership. ${ }^{13}$

\footnotetext{
${ }^{10}$ Anil Dawan, Op.Cit, p26

${ }^{11}$ Aman, Luis. (2009). Perempuanku Sayang Perempuanku Malang (Adat Belis in NTT and its Challenges for Female Emancipation), in Academic, No.2, VOL.VI, p51

${ }^{12}$ Finansia Clarita Gharu Leta. (2019). Belis Function in Kurulimbu Village Community, East Ndona District, Ende Flores Regency, East Nusa Tenggara, Journal of Morals and Citizenship, No. 2, VOL.7, p617

${ }^{13}$ Ibid
}

4 Wawan Suriadi, dkk | A Violation of Woman's Rights Under ... 
The practice of paying high Belis value often occurs in the people of East Nusa Tenggara. An interview conducted by Ulfah Cahaya Ningrum in 2016 in east Flores district stated that Belis payments to the Lamaholot Tribe of East Flores, East Nusa Tenggara reached hundreds of millions of rupiah more. Expensive Belis payments not only affect the inability of men to pay, but also give birth to the moral burden borne and must be repaid by the man ${ }^{14}$ if the amount of Belis has not been paid in full. This is because if the men have not been able to pay, then they can be allowed to be in debt in terms of Belis payments. Financial burden in the form of high Belis payments become a source of domestic problems that lead to violence against women. Truck-F women's division data shows that in 2015 there were 5 victims caused by Belis, in 2012 there were 9 people and in 2013 as many as 11 peoples. ${ }^{15}$

One of the most concerning in terms of women is the payment of high Belis often cause difficulties for women in order to access their rights. For example, in the nature of Belis traditional tradition, as a wife is required to serve the parents completely, should not return to her birth parents. When there is a problem, the woman should not go home to her birth parents. It then becomes a burden; life is not free and makes women feel like being likened to objects. A wife often gets domestic violence if she refuses to have sex with her husband. The irony is that when violence against the wife occurs, often this problem cannot be solved through legal channels. This is because domestic violence is a domestic problem that is considered taboo. A woman talking about the ugliness of her husband or vice versa and other domestic problems become taboo even to the parents themselves. ${ }^{16}$

Cases of violence against women in the household in Flores are caused by the attitude or way of thinking of the man who considers that the woman who is his bride in the sense that the wife is an item that has been paid off at a high price, so that he can do anything to his wife. ${ }^{17}$ On the other hand, women who are traditionally married and remain within the scope of their indigenous communities are also vulnerable to violence. These vulnerabilities are caused by several things. First, the husband who pays Belis feels that he has paid in full to get his wife. As a result, husbands often act arbitrarily towards wives, including violence. Second, from the aspect of indigenous peoples themselves, there is precisely preserving the acts of violence committed by men against women. Rarely do customary sanctions be imposed by customary elders, sometimes they also ignore the interests of women who are victims. For example,

\footnotetext{
${ }^{14}$ Ulfa Cahaya Ningrum,. (2016). Belis in Marriage tradition (Study of Lamaholot Community View in Larantuka, East Flores Regency, East Nusa Tenggara), Thesis, Faculty of Sharia, Maulana Malik Ibrahim State Islamic University, , p75

${ }^{15} \mathrm{http}: / /$ indonesiasatu.co/detail/hasil-survei-truk-f--Belis-penyebab-kdrt , accessed 22 January 2020

${ }^{16}$ Sipin Putra, Op.Cit, p50

${ }^{17}$ Roberto Octavianus Cornelis Seba, Op.Cit, p74
} 
in cases of sexual violence in the form of rape, often female rape victims are married to the perpetrator. ${ }^{18}$

\section{Protection of Women's Rights within the International Legal Framework}

The history of women's struggle for the elimination of all forms of discrimination against women has begun since 1967, coinciding with the issuance of a declaration of elimination of discrimination against women. Commission on the status of women/CSW. The United Nations (UN) made the declaration on the elimination of discrimination against women as the main foundation for the drafting of the convention on the elimination of all forms of discrimination against women and approved by the United Nations General Assembly (UN) on December 18, 1979. ${ }^{19}$

The Convention on the Elimination of All Forms of Discrimination against Woman is the world's first international treaty governing women's rights. The philosophical foundation of CEDAW is included in the first article, prioritizing the balance and equal rights between men and women in the public sphere.

CEDAW has three main principles. First, the principle of equality, which is an effort to look at substantive equality towards men and women. Second, the principle of non-discrimination, both gender discrimination and the fulfillment of basic freedoms and human rights. Third, the principle of obligation to the state, in this case the state is the main actor responsible for the realization of equality that the participating country is the main actor who has the responsibility to ensure the realization of equal rights of men and women in enjoying all economic, social, cultural, civil, and political rights. ${ }^{20}$

Article 5 of this convention points to prejudices and habits and all other practices based on the noted inferiority or superiority of one gender or based on the stereotypical role of men and women. ${ }^{21}$ The rest of Article 10 of this convention also requires states parties to take part in the elimination of discrimination against women and ensure equal rights between men and women in the field of Education. ${ }^{22}$

The Vienna Convention of 1993, the declaration focused on Human Rights by highlighting the Rights of Women in which declaring violence against women constitutes gender-based violence and all forms are in accordance with human dignity and self-esteem and should be abolished. The Declaration also affirms that Women's Rights must be an integral part of

\footnotetext{
${ }^{18}$ Tien Handayani Nafi, Lidiwina Inge Nurtjahyo, Iva Kusuma, et.al.(2016). Role of Customary Law in solving cases of violence against women in Kupang, Atambua, and Waingpu, , Journal of Law and Development, No.2, VOL 46, p234

${ }^{19}$ Maemun B. (2007). Protection of Women's Law from Domestic Violence in Human Rights Perspective, Thesis, Postgraduate Program, Faculty of Law Hasanudin University, p61-62

${ }^{20}$ Arifah Milati Agustina. (2016). Hak-Hak Perempun dalam Pengarusutamaan Ratifikasi Cedaw dan Maqasid AsySyari'ah, Al-Ahwal, No.2, VOL 9, p201

${ }^{21}$ Convention on the Elimination of Discrimination Against Woman, Article 5

${ }^{22}$ Convention on the Elimination of Discrimination Against Woman, Article 10
} 
all United Nations Human Rights activities, including in the promotion of all human rights instruments relating to women. ${ }^{23}$ In point 18 of this declaration states that the human rights of women are integral human rights, cannot be revoked or separated. The complete and equal participation of women in political, civil, economic, social, cultural life at the national, regional, and international levels, as well as the eradication of all forms of discrimination based on gender are the main objectives for the international community. ${ }^{24}$ Gender-based violence and all forms of sexual abuse and abuse, including those that occur due to cultural prejudice and international trade, are in conformed to the dignity and dignity of a human being, and should be abolished. This can be achieved by legal measures and through actions at the national level as well as international cooperation in areas such as economic and social development, education, maternity safety and health care, and social support. ${ }^{25}$ The World Conference on Human Rights urges all governments, institutions, intergovernmental organizations and nongovernmental organizations to promote their efforts in protecting and advancing human rights for women and girls. ${ }^{26}$

The concept of equality to ability is set forth in Points 36-37 which states that: ${ }^{27}$

The World Conference on Human Rights urges that human rights be enjoyed equally and fully by women, and for this to be a priority for governments and the United Nations. The World Conference on Human Rights also stressed the importance of fully integrating and participating women as agents and parties benefiting from the development process, as well as reaffirming the goals set on global action for women towards fair and sustainable development as set out in the Rio Declaration on Environment and Development and chapter 24 of Agenda 21, approved by the UN Conference on Environment and Development (Rio de Janeiro, Brazil, June 3-14, 1992).

Women's equal status and women's rights must be incorporated into the mainstream of all activities within the UN device. These issues must be regularly and systematically addressed to the relevant UN mechanism bodies. In particular, steps must be taken to enhance cooperation and advance the integration of further goals and objectives between the Women's Status Commission, the Human Rights Commission, the Commission for the Elimination of Discrimination against Women, the UN Development Fund for Women, the UN Development Program and other UN agencies. In this context, cooperation and coordination must be

${ }^{23}$ UNHCR, Viena Declaration and Programe of Action; Adopted by the World Conference of Human Rights in Vienna on June 25 1993, https://www.ohchr.org/en/professionalinterest/pages/vienna.aspx , accessed on 22 January 2021

${ }^{24}$ Viena Convention, Butir ke 18

${ }^{25}$ Ibid

${ }^{26} \mathrm{Ibid}$

${ }^{27}$ Vienna Declaration and Programme of Action, items 36-37 
strengthened between the Center for Human Rights and the Division for the Promotion of Women.

The declaration also fully supports the elimination of all forms of violence against women. This can be observed in point 38 which reads; ${ }^{28}$

In particular, the World Conference on Human Rights emphasizes the importance of efforts to eradicate violence against women in private and public life, the elimination of all forms of sexual harassment, the exploitation and illicit trafficking of women, the elimination of prejudice on the basis of gender in the administration of the law, as well as the extermination of any conflict that can occur between women's rights and the adverse effects of traditional practices or certain habits, cultural prejudices and religious extremism. The World Conference on Human Rights urged the UN General Assembly to approve the concept of a declaration on violence against women and urged countries to combat violence against women in accordance with applicable regulations. Violations of women's rights in situations of armed conflict are violations of international human rights principles and humanitarian law. All violations of this type, including murder, systematic rape, sexual slavery and forced pregnancy, demand a highly effective response.

Equal rights between men and women are regulated also in the International Convention civil and political rights, in Article 3 states: ${ }^{29}$

The States Parties to the Covenant pledge to guarantee equal rights for men and women to exercise the economic, social and cultural rights set forth in this Covenant.

Furthermore, this convention emphasizes the prohibition against violence, hatred, on the basis of racial and or group nationality as stipulated in Article 20; ${ }^{30}$

Any act that promotes hatred on the basis of nationality, race or religion that is incitement to discriminate, hostility or violence, should be prohibited by law.

The right of women to marry and form a family is also stipulated in Article 23 which reads "The right of adult men and women to marry and form a family shall be recognized". ${ }^{31}$

\section{The practice of giving Belis in international legal framework perspective.}

In this section will analyze whether the practice of giving Belis is a violation of international law if it is reviewed in terms of the consequences of the purchase itself. In order to answer that, the author will try to dissect from two sides: (a). high payment of Belis practices that often give birth to exploitation of women, (b). Belis practices that caused to superiority, violence

\footnotetext{
${ }^{28}$ Vienna Declaration and Programme Action, item 38

${ }^{29}$ International Convention Civil and Poltiical Rights, Article 3

${ }^{30}$ International Convention Civil and Political Rights, Article 20

${ }^{31}$ International Convention Civil and Political Rights, Article 23
} 
and restraint on women's rights. (c). People of East Nusa Tenggara with patrilineal customary system.

In previous discussions, the existence of dowry or Belis in NTT community tradition often raises some issues. One of them is the full control of women's rights, thus triggering violations of women's human rights. The restraint appears to be when a woman has a problem and is not allowed to return to her parents due to having to serve her husband completely. Such restraints also make women not free or independent. Deprivation of liberty is certainly contrary to the basic principles of freedom in human rights. The principles of human rights as stated in the UDHR (Universal Declaration of Human Right), some of which are recognition of basic dignity and equal rights as the basis of freedom, justice and world peace and equality between men and women. ${ }^{32}$ Further explanations regarding freedom of movement and equal rights can also be found in Article 2 of the UDHR which reads; ${ }^{33}$

Everyone has the right to all rights and freedoms contained in this Statement without exception whatsoever, such as race, color, gender, language, religion, politics or different opinions, national or societal origin, property rights, birth or other position.

Freedom of movement is also stipulated in Article 13 which reads "Everyone has the right to freedom of movement and to dwell within the borders of each country." If freedom of movement is part of the human rights listed in the UDHR, then what is it that when a woman is married and the consequence of marriage is the restriction of women's freedom of movement, is ${ }^{34}$ it a violation of human rights? This question arises due to the restraint of freedom of movement experienced by women as a consequence of the payment of Belis to the Indigenous Peoples of East Nusa Tenggara in general. Human rights violations constitute any act of a person or group of people including state officials whether intentional or unintentional or negligence that unlawfully reduces, obstructs, restricts, and or revokes the human rights of a person or group of people guaranteed by law. If it is based on such definition, the act of deterring women from moving in the Belis tradition is an act that violates human rights.

Highly rated Belis payments also often trigger domestic violence because the high Belis requested by the female family will have an impact on the financial viability of a family. This can be seen when there are not enough domestic needs in terms of material that ultimately give birth to disputes that lead to domestic violence. Not a little later woman become targets or victims of violence in this case. If so, the question arises whether the thing that triggered the violence should be prohibited, even if it is not contrary to human rights? Normatively,

\footnotetext{
${ }^{32}$ International Law Making, Universal Declaration of Human Rights, No. 1, October 2006, VOL. 4, Journal of International Law, p1

${ }^{33}$ Universal Declaration of Human Right, Article 2

${ }^{34}$ Universal Declaration of Human Right Article 13
} 
the value of Belis that is considered high enough cannot be prohibited even though it is one of the factors of violence against women. This is because first, no single norm in national or international law can prohibit cultural practice because it is a way of life of a society. Second, the act of setting the price of a dowry is an ability and not a violation of human rights in contrast to murder and other crimes that directly violate human rights. The act of giving Belis can be said to be prohibited if cause and effect is prohibited. But the element of prohibition exists only in the consequences of violence alone.

Then what about the issue of superiority in the family where in terms of decision making in the family with regard to women is often dominated by men. Are such actions justified according to human rights? Superiority in the universal view would be very contrary to the values of equality. The principle of equality means an idea that puts all people born free and has equality in human rights. Gender equality between men and women can also be demonstrated equal rights, responsibilities, opportunities, treatment, and judgment for men and women:

- on the job

- in the relationship between work and life.

Gender equality means that every one of all ages and genders should have an equal chance of succeeding in life. This means that all human beings must have access and control over equal resources and benefits, in other words fairly, so that everyone can benefit and participate in development. ${ }^{35}$ So that women's participation in terms of decision making is very necessary. In the tradition of Belis that often-put women in a very inferior position. ${ }^{36}$ Decision making is dominated by men although often these decisions will have an impact on the lives of women or wives.

Article 3 of the International Covenant Civil and Political Rights (ICCPR) states the obligations of states parties in the framework of equality; ${ }^{37}$

The States Parties to the Covenant pledge to guarantee equal rights for men and women to exercise the economic, social and cultural rights set forth in this Covenant.

The Vienna Convention 1993 in item 37 states that; ${ }^{38}$

The World Conference on Human Rights urges that human rights be enjoyed equally and fully by women, and for this to be a priority for governments and the United Nations. The

${ }^{35}$ Nelien Haspels and Busyakorn Suriyasan. (2005). Promoting Gender Equality in Action and Countering Child Labor and Trafficking in Women and Children, International Labour Organization, International Program for the Elimination of Child Labor, p.6

${ }^{36}$ Siti Rodliyah, Andrik Purwasito, Bani Sudardi, Wakit Abdullah. (2019). Between Economic Burden and Cultural Dignity, Belis in The Marittal Custom of NTT Society, Community : International Journal of Indonesian Society and Culture, No. 9, VOL.1, p.93

${ }^{37}$ ICCPR, Article 3

${ }^{38}$ Vienna Convention 1993, Article 36-37

10 Wawan Suriadi, dkk | A Violation of Woman's Rights Under ... 
World Conference on Human Rights also stressed the importance of fully integrating and participating women as agents and parties benefiting from the development process, as well as reaffirming the goals set on global action for women towards fair and sustainable development as set out in the Rio Declaration on Environment and Development and chapter 24 of Agenda 21, approved by the UN Conference on Environment and Development (Rio de Janeiro, Brazil, June 3-14, 1992).

Women's equal status and women's rights must be incorporated into the mainstream of all activities within the $\mathrm{UN}$ device. These issues must be regularly and systematically addressed to therelevantUNmechanismbodies. Inparticular, stepsmustbetakentoenhance cooperationand advancetheintegrationoffurthergoalsandobjectivesbetweentheWomen'sStatusCommission, the Human Rights Commission, the Commission for the Elimination of Discrimination against Women, the UN Development Fund for Women, the UN Development Program and other UN agencies. In this context, cooperation and coordination must be strengthened between the Center for Human Rights and the Division for the Promotion of Women.

Exploitation and violence against women are two elements that are strictly prohibited in international law. Declaration on the Elimination of Violence Against Women (UN 1973), in Article 1 of this Declaration states "acts of violence are gender-based violence directed at women whether physical, sex, or psychological, mental distress, including the restraint of freedom that occurs in both personal and political life." Article 20 of the ICCPR also affirms the ${ }^{39}$ prohibition of violence laws " Any act that promotes hatred on the basis of nationality, race or religion which is incitement to discriminate, hostility or violence, is prohibited by law." Further affirmation of the prohibition against violence. ${ }^{40}$

Based on the explanation above, it can be concluded that all acts of restraint of freedom of movement, and violence against women are two things that are not justified in the perspective of international law. The state is also required to ensure equality-based justice rights for women. Aspects of Belis tradition when viewed from the side of international law are allowed as long as the values promoted are values that are in accordance with the morality of humanity. Violence arising from the high value of Belis must be reviewed as the purpose of the giving of Belis itself where the purpose of Belis is to appreciate the nature of women and one of the ways to connect the family of the groom and the bride.

Actions that consider the full payment of Belis will result in the consequences of the transition of women's rights to men is an act that violates human rights and is contrary to the

\footnotetext{
${ }^{39}$ Prof. Dr. Komariah Emong et.al, Final Laporan Kompendum on Women's Rights, National Legal Development Agency, Ministry of Law and Human Rights, p12

${ }^{40}$ ICCPR, Article 20
} 
instruments of international law. This is because human rights are the right of nature as a gift of God that cannot be exchanged for a certain amount of money. Therefore, the giving of a number of Belis does not give birth to the transition of rights, but rather as an act to unite the family and respect the dignity and dignity of women.

\section{Legal aspects of state responsibility in protecting victims of violence against women as a result of Belis tradition.}

It has been explained in previous sections that there are many cases of violence against women as a result of Belis' high value. Ironically, cases of violence against women in some areas of East Nusa Tenggara are still considered taboo and often women as victims of domestic violence are not resolved through legal channels. ${ }^{41}$

The responsibility of the state arises if there is a violation of an international obligation to do something, whether the obligation is based on international treaties or based on international customs. Risk theory determines that a country is absolutely responsible for any activities that cause very harmful effects (harmful effects of hazardous activities) even though the activity is an activity that has legal legality. This theory then gave birth to the principle of absolute liability (absolute liability or strict liability) or objective ${ }^{42}$ responsibility. ${ }^{43}$

The country has ratified several instruments of international law and created national legislation in order to provide protection of women's human rights. The instruments of international law include; Convention on the Elimination of All Forms of Discrimination Against Women (UU no. 7/1984), International Convention on the Elimination of All Forms of Racial Discrimination, 1965 (UU no. 29/1999), International Covenant on Economic, Social, and Cultural Rights (UU no. 11/2005); International Covenant on Civil and Political Rights (Law no. 12/2005). ${ }^{44}$

Domestic legal instruments were also created in order to provide protection for women's rights. Some of the instruments of Indonesian law used to protect women's rights are; Law No.39 of 1999 on Human Rights, Law No. 23 of 2004 on the Elimination of Domestic Violence, Law No. 12 of 2006 on Citizenship, Law No. 21 of 2007 on the Eradication of Trafficking in People, Presidential Instruction No. 9 of 2000 on the mainstreaming of Gender, Presidential Regulation No. 65 of 2000 on the Commission against Violence against Women.

The prohibition against domestic violence is specifically regulated in Article 5 which reads; ${ }^{45}$

\footnotetext{
${ }^{41}$ Sipin Putra, Op.Cit, p50

${ }^{42}$ Andriy Sujatmoko, State Responsibility for Gross Violations of Human Rights, Indonesia East Timor and Others, Indonesia: Grasindo Gramedia Widiasarana, p28

${ }^{43}$ Huala Adolf, Aspects of the State in International Law, Jakarta: CV Rajawali

${ }^{44} \mathrm{https}$ //kemlu.go.id/portal/id/read/40/halaman_list_lainnya/indonesia-dan-hak-asasi-manusia, accessed 26 January 2021

${ }^{45}$ Law No. 23 of 2004 on the Elimination of Domestic Violence, Article 5
}

12 Wawan Suriadi, dkk | A Violation of Woman's Rights Under ... 
Everyone is prohibited from committing domestic violence against people in the scope of their household, by means of:

a. physical violence;

b. psychic violence;

c. sexual violence; Or

d. household neglect.

As an effort to protect women, the law on the elimination of domestic violence, namely Law No. 23 of 2004, in Article 16 within 1x24 hours after receiving the complaint report is required to act to provide temporary protection to the victim. ${ }^{46} \mathrm{Temporary}$ protection is provided by involving the police by working with health workers, social workers, accompanying volunteers, and or spiritual mentors to assist victims. ${ }^{47}$ Article 44 of this Law provides criminal provisions for perpetrators of domestic violence; ${ }^{48}$

Every person who commits acts of physical violence within the scope of the household as referred to in Article 5 letter a is sentenced to a maximum imprisonment of 5 (five) years or a maximum fine of Rp15,000,000.00 (fifteen million rupiah).

In the case that the act as referred to in paragraph (1) results in the victim getting sick or seriously injured, shall be penalized with a maximum imprisonment of 10 (ten) years or a maximum fine of Rp30,000,000.00 (thirty million rupiah).

In the case that the act as referred to in paragraph (2) results in the death of the victim, shall be penalized with a maximum imprisonment of 15 (fifteen) years or a maximum fine of Rp. 45,000,000.00 (forty five million rupiah). (4) In the event that the act as referred to in paragraph (1) is committed by the husband against the wife or vice versa that does not cause illness or obstacles to carry out office work or livelihood or daily activities, shall be penalized with imprisonment of maximum 4 (four) months or a maximum fine of Rp. 5,000,000.00 (five million Rupiah).

The establishment of state institutions at the national level based on the Law is also carried out to fulfill the responsibility of the state in providing maximum protection to women. The institution is the National Commission against Violence Against Women (KOMNAS Perempuan) which was established through the Presidential Regulation Law No. 25 of 2000. The National Commission against Violence Against Women (KOMNAS Perempuan) as a representative of the state has a role (a). develop conditions conducive to the elimination of all

\footnotetext{
${ }^{46}$ Law No. 23 of 2004, on the Elimination of Domestic Violence

${ }^{47}$ Law No. 23 of 2004, on the Elimination of Domestic Violence, Article 17

${ }^{48}$ Law No. 23 of 2004, On the Elimination of Domestic Violence, Article 44
} 
forms of violence against women and the enforcement of women's human rights in Indonesia, (b). improve efforts to prevent and counteract all forms of violence against women and the protection of women's human rights. ${ }^{49}$

The presence of several international instruments and the number of laws and regulations in writing does not guarantee the cleanness of violence against women. So that the responsibility of the state is not only limited to forming a national legislature program that leads to the establishment of legislation related to an issue, but the responsibility of the state must also guarantee the implementation of norms, principles, objectives of the formation of such legislation.

\section{CONCLUSION}

The existence of Belis tradition that sets high standards of dowry in tribal weddings in East Nusa Tenggara Indonesia is the trigger for violence against women in the household. This is due to a growing perception that men have paid the Belis value where there is a transition of women's rights to men who have paid Belis. Actions that consider the full payment of Belis will result in the consequences of the transition of women's rights to men is an act that violates human rights and is contrary to the instruments of international law. This is because human rights are the right of nature as a gift of God that cannot be exchanged for a certain amount of money. Therefore, the giving of a number of Belis does not give birth to the transition of rights, but rather as an act to unite the family and respect the dignity and dignity of women.

The State of Indonesia has actively participated in ratifying the instruments of international law in an effort to protect human rights. However, the large number of legal instruments relating to human rights does not guarantee the occurrence of good human rights enforcement. The responsibility of the state is not only to create the product of national legislature, but it must ensure the implementation of the goals, principles and ideals enshrined in the product of the legislation. The State of Indonesia must also actively participate in the supervision and supervision by not only involving the state apparatus but also community leaders, religious and indigenous leaders. Their involvement in this can reform the perceptions that arise in society about the Belis tradition that often gives birth to domestic violence.

\section{Bibliography}

\section{Book. Scientific Articles, Journals, report research results}

Aman, Luis. (2009). Perempuanku Sayang Perempuanku Malang (Adat Belis in NTT and its Challenges for Female Emancipation), in Academic, No.2, VOL.VI.

\footnotetext{
${ }^{49}$ Presidential Regulation No. 65/2005 on The National Commission against Violence Against Women, Article 2
} 
Anil Dawan. (2019). Alor Woman in Belis Cultural Vortex; An Ethnographic Approach Through Cultural Revitalization, Jurnal Inada. No.1, VOL.2,

Arifah Milati Agustina. (2016). Hak-Hak Perempun dalam Pengarusutamaan Ratifikasi Cedaw dan Maqasid Asy-Syari'ah, Al-Ahwal, No.2, VOL 9, Al-Ahwal.

Andrey Sujatmoko, Tanggung Jawab Negara Atas Pelanggaran Berat Hak Asasi Manusia, Indonesia Timor Leste dan Lainnya, Indonesia: Grasindo Gramedia Widiasarana.

Finansia Clarita Gharu Leta.(2019) Belis Function in Kurulimbu Village Community, East Ndona District, Ende Flores Regency, East Nusa Tenggara, Journal of Morals and Citizenship, No 2, Vol 7.

Huala Adolf, Aspek-aspek Negara dalam Hukum Internasional, Jakarta: CV Rajawali.

International Law Making. (2006). Deklarasi Universal Hak Asasi Manusia, No. 1, Jurnal Hukum Internasional, No 1, Vol 4.

Lisa H, Development Challenge in NTT, No. 20, The Smeru Research Institute.

Maemun B. (2007). Protection of Women's Law from Domestic Violence in Human Rights Perspective, Thesis, Postgraduate Program, Faculty of Law Hasanudin University.

Nelien Haspels dan Busyakorn Suriyasan. (2005). Meningkatkan Kesetaraan Gender dalam Aksi dan Penanggulangan Pekerja Anak serta Perdagangan Perempuan dan Anak, International Labour Organization, Program Internasional Penghapusan Pekerja Anak.

Prof. Dr. Komariah Emong et.al, Final Laproan Kompendum tentang Hak-Hak Perempuan, Badan Pembangunan Hukum Nasional, Kementerian Hukum dan HAM.

Romy Patra, Institutional Effectiveness of Komnas Perempuan in Protecting Human Rights for Women in Indonesia

Sipin Putra, (2010), Women's Opportunity to Get Reproductive Health Services and Rights in Alor Countryside, East Nusa Tenggar, Jurnal Inada, No 1, Vol 2.

Siti Rodliyah, Andrik Purwasito, Bani Sudardi, Wakit Abdullah. (2019). Between Economic Burden and Cultural Dignity, Belis in The Marittal Custom of NTT Society, Komunitas : Internasional Journal of Indonesian Society and Culture, No 9, Vol 1.

Tien Handayani Nafi, Lidwina Inge Nurtjahyo. (2016). Iva Kusuma, Tirtawening Parikesit, The Role of Customary Law in Resolving Cases of Violence Against Women in Kupang, Atambua, and Waingpu, No.2,VOL 46.

Theresia Christiana Nuwa. (2019). Meaning Belis as Dowry (Case Study on Married Couples Using Belis and Without Belis In Nageko Flores Community, East Nusa Tenggara), Thesis, Department of Communication Sciences, FISIP, Airlangga University.

Tien Handayani Nafi, Lidiwina Inge Nurtjahyo, Iva Kusuma, et.al. (2016). Role of Customary Law in solving cases of violence against women in Kupang, Atambua, and Waingpu, Journal of Law and Development, No 2, Vol 46.

Ulfa Cahaya Ningrum. (2016). Belis in Marriage tradition (Study of Lamaholot Community View in Larantuka, East Flores Regency, East Nusa Tenggara), Thesis, Faculty of Sharia, Maulana Malik Ibrahim State Islamic University. 


\section{Laws And Regulations}

Convention on the Elimination of Discrimination Against Woman

International Convention Civil and Political Rights

Peraturan Presiden Republik Indonesia No 65 Tahun 2005 tentang Komisi Nasional Anti Kekerasan Terhadap Perempuan, Article 2

Undang-Undang No 23 Tahun 2004 tentang Penghapusan Kekerasan dalam Rumah Tangga,

Vienna Declaration 1994

Universal Declaration of Human Rights

\section{Site}

http://www.jurnalperempuan.org/warta-feminis/kekerasan-terhadap-perempuan-meningkatdelapan-kali-lipat-selama-12-tahun-terakhir

https://health.detik.com/berita-detikhealth/d-3078669/kekerasan-seksual-di-balik-maharperkawinan-di-alor-NTT,

http://indonesiasatu.co/detail/hasil-survei-truk-f--Belis-penyebab-kdrt

https://kemlu.go.id/portal/id/read/40/halaman_list_lainnya/indonesia-dan-hak-asasi-manusia, 